\title{
Some Heavy Metals' Concentrations in Roadside Dusts at Monte Christo, Windhoek Namibia
}

\author{
S. A. Onjefu, J. Abah, and B. Nambundunga
}

\begin{abstract}
The main objective of this study was to assess the concentrations of some heavy metals of human health importance in the roadside dusts across three major locations in Monte Christo, Windhoek and compare the values with regulatory maximum permissible limits. Eighteen (18) samples of the roadside dusts (consisting of 6 each) were collected from both sides of the road at Hereford street, Fuel service station, and Traffic junction. The samples were digested using EPA method 3050B and analyzed for the heavy metals' concentrations using Inductively Coupled Plasma-Optical Emission Spectrophotometer (ICP: Perkin Elmer Optima 7000 DV). The overall mean concentrations $(\mathrm{mg} / \mathrm{kg})$ of the heavy metals recorded across the sampling sites follow the order: $\mathrm{Fe}>\mathrm{Mn}>\mathrm{Zn}>\mathrm{Cu}>\mathrm{Pb}>\mathrm{Cr}>\mathrm{Ni}$. Result of the analysis of variance between the mean concentrations of the heavy metals was statistically significant (Anova: single factor, $\mathrm{p}<0.05$ ). Although, the present concentrations of the heavy metals were generally lower than their health regulatory maximum permissible limits in soils, the enrichment factors revealed deficient to minimal $(2<\mathrm{EF}<5)$ and significant indices $(5<\mathrm{EF}$ $<20)$. These are related to anthropogenically induced contaminations. There are strong positive correlations between the mean levels of the heavy metals which suggest common sources of anthropogenic inputs. It is therefore, recommended that the impact of the sources of metals emission on heavy metals' accumulations in the area should be established with a view to advising precautionary measures that could minimize unintended exposure of the populace.
\end{abstract}

Index Terms-Heavy metals, roadside dusts, enrichment factor, Monte Christo.

\section{INTRODUCTION}

In recent years, there has been an increasing ecological and global public health concern associated with environmental contamination by heavy metals [1]. The accumulations of heavy metals in the human environments continue to generate safety concern due to their non-degradability and accumulative tendencies [2]. Several researchers have indicated the need for a better understanding of metal pollutions of roadside soils [3], [4]. Moreover, the presence of heavy metals has been considered as useful indicators for

Manuscript received June 23, 2017; revised August 30, 2017. This work was supported in part by the Institutional Research and Publication Committee (IRPC) of the Namibia University of Science and Technology under its research funding programme.

S. A. Onjefu is with the Department of Natural and Applied Sciences, Namibia University of Science and Technology, Private Bag, 13388, Windhoek, Namibia (e-mail: sonjefu@nust.na).

J. Abah is with the Department of Mathematics, Science and Sport Education, Faculty of Education, University of Namibia, Katima Mulilo Campus, Private Bag, 1096, Katima Mulilo Namibia (e-mail: jabah@unam.na).

B. Nambundunga is with the Department of Health Sciences, Namibia University of Science and Technology, Private Bag, 13388, Windhoek, Namibia (e-mail: bnambundunga@gmail.com). contaminations in surface soil, sediment and dust environments [5]. Although, considerable number of studies on heavy metals concentration of roadside dusts have been reported in the developed countries with long histories of industrialization [6], [7], the effects of progressive and localized anthropogenic activities on trace metals concentration of environmental indices need to be evaluated in the developing countries to monitor the trend of the relationship between emission source and concentrations [8].

Urban roadside dusts consist of vehicular exhaust particles, household dust, soil dust, construction dust and aerosols that are carried freely by air and water [9]-[11]. Road dusts are often contaminated by heavy metals and organic matters [12]. Anthropogenic sources of heavy metals in urban road dusts include traffic emission (vehicle exhaust particles, tire wear particles, weathered street surface particles, brake lining wear particles), industrial emission (power plants, coal combustion, metallurgical industry, auto repair shop, chemical plant), domestic emission, weathering of building and pavement surface, atmospheric depositions etc [13]-[16]. Road dust does not remain deposited in place for long but are easily re-suspended back into the atmosphere, where it contributes a significant amount of trace elements [12]. Two main sources of road dust, and consequently of the heavy metals found therein include deposition of previously suspended particles (atmospheric aerosols) and displaced soil [17]. However, particles of different fraction sizes have different modes of transport [18]. Research findings have shown that strong wind is an important factor in the trans-boundary effects of dust particles affecting regional environment, harming human health and causing significant impacts on global biogeochemical cycle [19], [20].

Roadside dusts are freely inhaled by people traversing the road as well as living within its vicinity, and the more the dusts are contaminated with heavy metals, the more people are exposed to the health hazards associated with such metals [8]. Thus, the determination of metal levels in environmental samples: soils and urban roadside dusts are necessary steps for monitoring environmental pollution since such levels can affect the surrounding ecosystems including bioaccumulation in organisms [21]. Particle size and chemical compositions of dust could decide the significant impact of dust on air quality, public health, and climate [22]. Particulates of smaller sizes such as dust are persistent in the environment and exert negative health impact to the exposed resident population, especially in the urban settings [23]. In fact, the health effects of toxic metals in atmospheric and roadside dusts on humans is better appreciated if one considers the fact that an active person typically inhales $10,000 \mathrm{~L}$ to $20,000 \mathrm{~L}$ of air daily [21].

Interest in heavy metal exposures has further been intensified among populations previously thought to be less 
vulnerable to such exposures and unexpected points of exposure intersection have been identified, resulting in enormous concern [24]. Due to the growing concern for the potential contribution of ingested dusts towards heavy metal toxicities in humans - with children being more vulnerable [8]; it is quite pertinent to investigate the levels of heavy metals of environmental and human health importance in roadside dusts of Monte Christo, a very busy location with high human activities in Windhoek metropolis. This study provides baseline data of the levels of some heavy metals in roadside dusts within Monte Christo, Windhoek and it is envisaged that the information could be useful for the development of regulatory protections to limit unintended occupational and environmental exposures of the populace in the study area.

\section{MATERIALS AND MethodS}

\section{A. Study Area}

Monte Christo is a very busy location with high human activities in Windhoek, the capital city of Namibia. The area housed a very busy bus terminal, and other business outlets such as entertainment facilities (e.g. bars), hair cutting and dressing salons, fuel service station and vast petty businesses such as street vending. The area also has high traffic congestion on a daily basis as it serves as one of the main links from city center to Katutura suburb of Windhoek. Among the street vendors selling food items along the sides of the road, majority of the items are either poorly covered or not covered at all and hence, are freely exposed to the roadside dusts. Thus, apart from population exposures via dusts inhalation and dermal contact, consumers of these exposed food items are likely to be at a higher risk of exposure to the roadside dusts contaminations. This makes it imperative to assess the pollutants levels such as heavy metals concentrations of the roadside dusts in the study area.

\section{B. Sample Collection}

The roadside dusts samples were collected according to the modified method described by [8]. A total of eighteen (18) samples of the roadside dusts (consisting of 6 subsamples each) were collected from both sides of the road at three different locations: Hereford street, Fuel service station, and Traffic junction. Table I shows the coordinates of the sampling points and description of the sites' major activities. Samples were collected in the morning hours between $06 \mathrm{~h} 00$ and $07 \mathrm{~h} 00$ while the dust has settled well throughout the night and before heavy morning traffic movement that can disrupt the dust [8]. The samples were collected from both sides of the road by sweeping surface dust into plastic waste packers using plastic brush and then transferred into pre-labelled polythene bags. All irrelevant materials such as cigarette ends, papers, plastics etc. were carefully hand-picked and the dusts exposed to air-drying under atmospheric temperature for five days [8]. Thereafter, samples collected at each location were ground together thoroughly to ensure homogeneity and filtered through 75 $\mu \mathrm{m}$ stainless steel sieve [8]. Dusts particles ranging from $75-125 \mu \mathrm{m}$ contain have been reported to contain high levels of heavy metals and are also known to be very harmful to humans if inhaled [25], [26]. The samples were then taken to the Namwater Analytical Laboratory Services in Windhoek for further processing and analysis. All the materials used to hold or collect samples were pre-cleaned to avoid possible contamination of the samples.

\section{Sample Digestion and Analysis}

The dust samples were digested according to EPA method $3050 \mathrm{~B}$ as described by [8]. For each sample, $1.00 \mathrm{~g}$ of sieved dusts was transferred into a digestion vessel and $10 \mathrm{~mL}$ of $1: 1$ nitric acid was added, mixed thoroughly and covered with a watch glass. Then, the solution was heated to $90^{\circ} \mathrm{C}$ and refluxed at this temperature for 10 minutes and allowed to cool for 5 minutes under room temperature. After cooling, $5 \mathrm{~mL}$ of concentrated nitric acid was added, covered and refluxed again at $90^{\circ} \mathrm{C}$ for 30 minutes. The solution was allowed to evaporate without boiling to approximately $5 \mathrm{~mL}$ and cooled again for 5 minutes. Then, $2 \mathrm{~mL}$ of deionised water plus $3 \mathrm{~mL}$ of $30 \%$ hydrogen peroxide were added and the vessel was then covered and heated just enough to warm the solutions for the peroxide reaction to start [27]. This was continued until effervescence subsided and the solution was cooled [8]. Again, the solution was covered with watch a glass and heated until the volume reduced to approximately $5 \mathrm{~mL}$. Then, $10 \mathrm{~mL}$ of concentrated hydrochloric acid was added, covered and heated on a heating mantle, then refluxed at $90^{\circ} \mathrm{C}$ for 15 minutes. After cooling, the digested solution was filtered through Whatman No. 41 filter paper into a $100 \mathrm{~mL}$ volumetric flask and the volume made up to the mark with deionised water [27].

The digested solutions were analyzed for the levels of arsenic, cadmium, chromium, lead, nickel, copper, iron manganese and zinc using Inductively Coupled Plasma-Optical Emission Spectrophotometer (ICP: Perkin Elmer Optima 7000 DV).

\section{Data Analysis and Site Contamination Assessment}

The Statistical Package for Social Sciences (SPSS) software version 23 was used to calculate the mean of the heavy metals. The site contamination was assessed using the criteria of contamination factor $(\mathrm{CF})$, degree of contamination $\left(\mathrm{C}_{\mathrm{d}}\right)$, combined pollution index $(\mathrm{CPI})$ and enrichment factor (EF) (Table II and III) [27], [28]. These contamination criteria were calculated using the following equations [8], [28].

$$
\begin{gathered}
\mathrm{Cf}=\frac{\text { Soil metal concentration }}{\text { soil permissible limit of the metal }} \\
\mathrm{C}_{\mathrm{d}}=\sum_{i=1}^{N} \mathrm{CF} i \\
\mathrm{CPI}=\frac{\text { Soil metal concentration } / \mathrm{PMC}}{\text { Number of metal determined }} \\
\mathrm{EF}=\frac{\mathrm{C} / \mathrm{Fe}(\text { sample })}{\mathrm{C} / \mathrm{Fe}(\text { Earth } \text { crust })}
\end{gathered}
$$

\begin{tabular}{|c|c|c|c|}
\hline \multirow{3}{*}{$\begin{array}{l}\text { Sampling } \\
\text { point }\end{array}$} & \multicolumn{2}{|c|}{ Geographical } & \multirow{3}{*}{$\begin{array}{l}\text { Site } \\
\text { characteristics }\end{array}$} \\
\hline & \multicolumn{2}{|c|}{ coordinates } & \\
\hline & Latitude & Longitude & \\
\hline $\begin{array}{l}\text { Hereford } \\
\text { street } \\
\text { location } \\
1 .\end{array}$ & $\mathrm{S} 22^{\circ} 30^{\prime} 39.85^{\prime \prime}$ & $\mathrm{E} 17^{\circ} 03^{\prime} 37.48^{\prime \prime}$ & $\begin{array}{l}\text { Heavy vehicle } \\
\text { traffic and } \\
\text { commercial }\end{array}$ \\
\hline
\end{tabular}

TABLE I: GEOGRAPHICAL COORDINATES OF SITE CHARACTERISTICS OF THE 


\begin{tabular}{|c|c|c|c|}
\hline & & & \multirow{6}{*}{ activities } \\
\hline 2. & $\mathrm{~S} 22^{\circ} 30^{\prime} 36.91^{\prime \prime}$ & $\mathrm{E} 17^{\circ} 03^{\prime} 36.08^{\prime \prime}$ & \\
\hline 3. & $\begin{array}{l}\mathrm{S} 22^{\circ} 30^{\prime} \\
33.52^{\prime \prime}\end{array}$ & E1703'35.51" & \\
\hline 4. & $\mathrm{~S} 22^{\circ} 30^{\prime} 47.35^{\prime \prime}$ & $\mathrm{E} 17^{\circ} 03^{\prime} 36.59^{\prime \prime}$ & \\
\hline 5. & $\begin{array}{l}\mathrm{S} 22^{\circ} 30^{\prime} \\
41.52^{\prime \prime}\end{array}$ & E17 03'38.51" & \\
\hline 6. & $\mathrm{~S} 22^{\circ} 30^{\prime} 40.50^{\prime \prime}$ & E17 03 '38.51" & \\
\hline $\begin{array}{l}\text { Fuel service } \\
\text { location } \\
1 .\end{array}$ & $\mathrm{S} 22^{\circ} 30^{\prime} 40.65^{\prime \prime}$ & $\mathrm{E} 17^{\circ} 03^{\prime} 25.78^{\prime \prime}$ & \multirow{6}{*}{$\begin{array}{l}\text { High } \\
\text { commercial } \\
\text { activities, high } \\
\text { vehicle traffic, } \\
\text { location of van } \\
\text { Eck Power } \\
\text { Station }\end{array}$} \\
\hline 2. & $\mathrm{~S} 22^{\circ} 30^{\prime} 42.31^{\prime \prime}$ & E17 $03^{\prime} 30.78^{\prime \prime}$ & \\
\hline 3. & S22 $30^{\prime} 44.71^{\prime \prime}$ & E17 03'35.10" & \\
\hline 4. & S22 $30^{\prime} 46.14^{\prime \prime}$ & $\mathrm{E} 17^{\circ} 03^{\prime} 50.48^{\prime \prime}$ & \\
\hline 5. & $\mathrm{~S} 22^{\circ} 30^{\prime} 47.13^{\prime \prime}$ & $\mathrm{E} 17^{\circ} 03^{\prime} 57.21^{\prime \prime}$ & \\
\hline 6. & $\mathrm{~S} 22^{\circ} 30^{\prime} 49.90^{\prime \prime}$ & $\mathrm{E} 17^{\circ} 03^{\prime} 61.55^{\prime \prime}$ & \\
\hline \multicolumn{4}{|l|}{$\begin{array}{l}\text { Traffic } \\
\text { junction }\end{array}$} \\
\hline $\begin{array}{l}\text { location } \\
1 .\end{array}$ & $\mathrm{S} 22^{\circ} 30^{\prime} 43.23^{\prime \prime}$ & 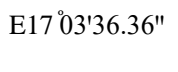 & \multirow{6}{*}{$\begin{array}{l}\text { High vehicle } \\
\text { traffic and } \\
\text { pedestrian }\end{array}$} \\
\hline 2. & $\mathrm{~S} 22^{\circ} 30^{\prime} 44.81^{\prime \prime}$ & E17 $03^{\prime} 39.45^{\prime \prime}$ & \\
\hline 3. & S22 $30^{\prime} 42.13^{\prime \prime}$ & E1703'42.51" & \\
\hline 4. & $\mathrm{~S} 22^{\circ} 30^{\prime} 43.71^{\prime \prime}$ & $\mathrm{E} 17^{\circ} 03^{\prime} 37.54^{\prime \prime}$ & \\
\hline 5. & S22 $30^{\prime} 45.67^{\prime \prime}$ & E17 $03^{\prime} 41.69^{\prime \prime}$ & \\
\hline 6. & S22 $30^{\prime} 49.76^{\prime \prime}$ & E17 $03^{\prime} 43.24^{\prime \prime}$ & \\
\hline
\end{tabular}

where $n=$ number of elements detected, PMC $=$ soil maximum permissible concentration of a particular metal, $\mathrm{C} / \mathrm{Fe}($ sample $)=$ ratio of the sample's metal concentration to $\mathrm{Fe}$ concentration of the sample, and $\mathrm{C} / \mathrm{Fe}($ earth crust $)=$ ratio of the sample's metal concentration to Fe concentration of the earth crust. The earth's crust Fe concentration used here was the value reported in the "Nature's building blocks: an A-Z guide to the element" [29]. Some studies have proposed iron as an acceptable normalization element in the calculation of enrichment factors since its distribution in the earth crust was not related to other heavy metals [30].

\section{RESUlTS AND DisCUSSION}

\section{A. Concentrations of the Heavy Metals in the Roadside Duists in Monte Christo}

Fig. 1 presents the concentrations $(\mathrm{mg} / \mathrm{kg})$ of the heavy metals determined per sampling site in the study area. Among the three sampling sites, the Fuel service station location recorded the highest levels of the heavy metals followed by Hereford street and least at the traffic junction location. The result of the analysis of variance between the mean concentrations of the heavy metals across the sampling sites (Table II) was statistically significant (anova: single factor, $p<0.05$ ). The highest levels of the heavy metals recorded in the Fuel service station location may be due to the presence of major sources of heavy metal emissions such as high vehicle movements ( 24 hours) in and out of the fuel service station, and close proximity to Van Eck power station, a 120 megawatt (MW) coal-fired power station in the northern industrial area of Windhoek [31].

The mechanisms of heavy metals emission from vehicles consist of fuel consumption, engine oil consumption, tire wear, brake wear, and road abrasion [32]-[34]. Due to more intense driving conditions of vehicles in and out of fuel station particularly, in the sampling area with high presence of human traffics, heavy metals accumulation and distribution in the roadside dust collected around the fuel station could be indeed higher than the other two sampling points. In a study on heavy metal emissions for Danish road transport, it was reported that engine oil consumption accounts for the largest emission of $\mathrm{Cd}$, tire wear constitutes the most important emission of $\mathrm{Zn}$, while brake wear is the most important source of emission of $\mathrm{Cu}$ and $\mathrm{Pb}$ [34], although $\mathrm{Cd}$ was not detected in this study. According to IEA Clean Coal Centre [35], combustion of coal is a potential source of several trace element emissions to the atmosphere, including heavy metals. Combustion processes are considered the most important sources of heavy metals particularly power generation, smelting, incineration and the internal combustion engine [35]. Thus, the close proximity of Van Eck power station to the Fuel service station sampling area could influence the concentrations of the heavy metals recorded in the samples collected in this location.

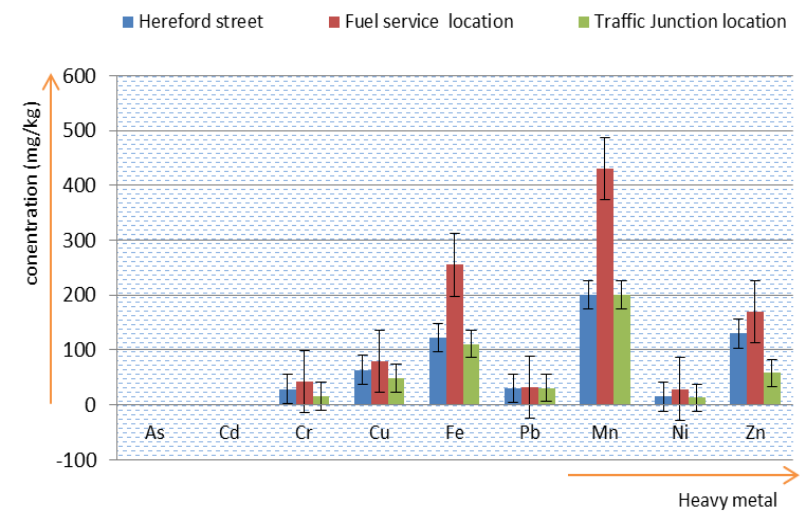

Fig. 1. Concentrations $(\mathrm{mg} / \mathrm{kg})$ of the heavy metals in the sampling points Key: $\mathrm{Fe}=10^{2}$.

As presented in Fig. 2, the overall mean concentrations $(\mathrm{mg} / \mathrm{kg})$ of the heavy metals recorded across the sampling sites follow the order: $\mathrm{Fe}>\mathrm{Mn}>\mathrm{Zn}>\mathrm{Cu}>\mathrm{Pb}>\mathrm{Cr}>\mathrm{Ni}$. As and $\mathrm{Cd}$ were not detected. The highest mean concentration of iron $(16,300 \mathrm{mg} / \mathrm{kg})$ recorded in this study may be due to its natural sources $(1.5 \%)$ which vastly dominate its input in an environment [8]. Generally, all the mean levels of the heavy metal were lower than soil regulatory maximum permissible limits for the protection of human health as shown in Table III above. However, once heavy metals enter the environment, they are not degradable and hence, could accumulate to potentially toxic levels. Studies have shown that the threat posed by heavy metals to the health of living organisms is worsened by their continuously persistent nature in the environment [36]. Metal toxicity is shown in their ability to disrupt enzyme structures and functions by binding with thiol and protein groups, or by replacing co-factors in prosthetic groups of enzymes [36].

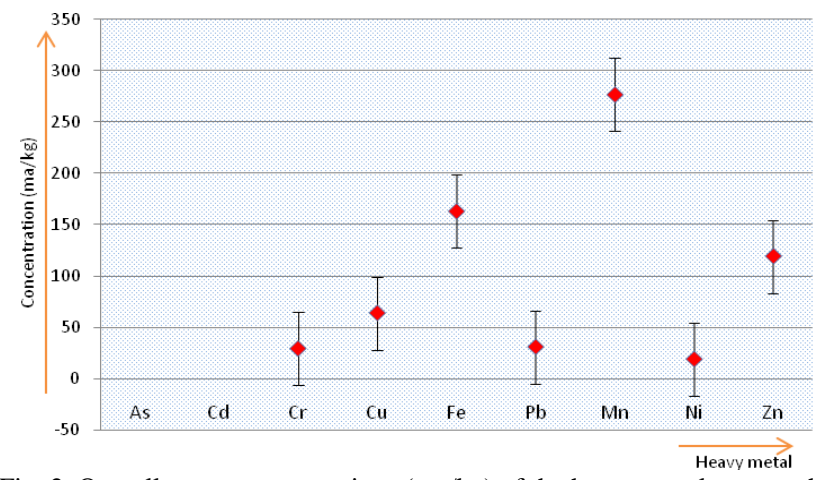

Fig. 2. Overall mean concentrations $(\mathrm{mg} / \mathrm{kg})$ of the heavy metals across the sampling points Key: $\mathrm{Fe}=10^{2}$ 
TABLE II: ANOVA: Single FACTOR OF THE HEAVy METAL LEVELS ACROSS THE SAMPLiNG POINTS

\begin{tabular}{lcrrrr}
\hline Source of Variation & SS & Df & MS & \multicolumn{1}{c}{ P } & -value \\
\hline Between Groups & 159494.7 & 6 & 26582.44 & 6.712012 & 0.001643 \\
Within Groups & 55446 & 14 & 3960.429 & & \\
Total & 214940.7 & 20 & & & \\
\hline ally significant at $\mathrm{p}<0.05 ; \mathrm{F}>$ Fcrit & & & &
\end{tabular}

Statistically significant at $\mathrm{p}<0.05 ; \mathrm{F}>$ Fcrit
TABLE III: MAXIMUM PERMISSIBLE CONCENTRATION (MPC) OF THE HEAVY METALS IN SOIL

\begin{tabular}{|c|c|c|c|c|c|c|c|c|c|}
\hline Heavy metal & $\mathrm{As}$ & $\mathrm{Cd}$ & $\mathrm{Cr}$ & $\mathrm{Cu}$ & $\mathrm{Pb}$ & $\mathrm{Mn}$ & $\mathrm{Ni}$ & $\mathrm{Zn}$ & $\mathrm{Fe} *$ \\
\hline CAS. No & $7440-38-2$ & $7440-43-9$ & $7440-47-3$ & $7470-50-8$ & $7439-92-1$ & $7439-92-1$ & $7440-02-0$ & $7440-66-6$ & $7440-66-6$ \\
\hline MPC $(\mathrm{mg} / \mathrm{kg})$ & 10 & 3 & 100 & 100 & 100 & 1500 & 75 & 200 & 50000 \\
\hline
\end{tabular}

Source: [8]; MPC = Maximum permissible poncentration, $*=[37]$

\section{B. Assessment of the Roadside Dusts Pollution Criteria}

The contamination factor $(\mathrm{CF})$ is a single element pollution index calculated in order to determine the individual contribution of the heavy metals to a sampling site's pollution [38]. The results of the heavy metals contamination factors of the roadside dusts across the three sampling sites (Fig. 3) ranged between $0.13(\mathrm{Mn})$ to $0.85(\mathrm{Zn})$ and these revealed low contamination status $(\mathrm{CF}<1)$. The combined pollution index (CPI) of the heavy metals (also in Fig. 3) showed similar trend; the results varied between 0.022 $(\mathrm{Mn})$ to $0.145(\mathrm{Zn})$. The CPI values are less than one and suggest that average levels of the metals are below their selected reference standards but do not necessarily indicate that there are no anthropogenic sources of enrichment over background level [8], [39].

The degree of contamination $(\mathrm{Cd})$ of the heavy metals was also computed with the aim of providing the measure of the overall contamination in the roadside dust at a particular sampling site [40]. The results (Figure 4 below) revealed that the Fuel service station area is most affected by the heavy metals contamination. This trend suggested that the Fuel service station area received more heavy metals input from anthropogenically induced sources [8]. This is a likely effect as the area witnessed high vehicle movements in and out of the fuel service station and is close to Van Eck power station.

The soil enrichment factors of the heavy metals (Figure 5 below) revealed that the results varied between: $0.02(\mathrm{Zn})$ to $5.04(\mathrm{Cu})$ at the Herefort street, $0.01(\mathrm{Zn}$ and $\mathrm{Mn})$ to $3.00(\mathrm{Cu})$ at the Fuel service location and $0.01(\mathrm{Zn})$ to $4.28(\mathrm{Zn})$ at the Traffic junction location. Based on the referenced criteria for classification of the heavy metals' enrichment factors of the roadside dusts (Table IV below), the present levels of $\mathrm{Mn}, \mathrm{Ni}$ and $\mathrm{Zn}$ showed deficient to minimal indices of enrichment $(\mathrm{EF}<2) ; \mathrm{Cu}, \mathrm{Cr}$ and $\mathrm{Pb}$ showed moderate indices of enrichment $(2<\mathrm{EF}<5)$. In particular, $\mathrm{Cu}$ (5.04) recorded significant index of enrichment at the Herefort street $(5<\mathrm{EF}$ $<20$ ). Some of these heavy metals (e.g. $\mathrm{Pb}, \mathrm{Cr}$ ) have been identified among the toxic elements that will continue to accumulate in urban environment due to their non-biodegradability and long residence time [8]. In a related opinion, [41] stated that once present, heavy metals are persistent environmental contaminants. Apart from causing acute or chronic poisoning, heavy metals can be transferred from one generation to another with potential toxicity from the viewpoint of public health [42].

Thus, due to the frequent human exposures and interactions with the sampling sites, the heavy metals' enrichment of the environment could constitute health safety concern due to ingestion and bioaccumulation into body tissues. In this regard, the need to assess the distributions of heavy metals in the surface soils, which serve as an important sink, in order to understand the overall status of heavy metal pollution and the associated ecological risk in a region is of importance [43]. Such results could provide useful information guide for the management plan of an environment such as Monte Christo of Windhoek undergoing fast developmental transformation.

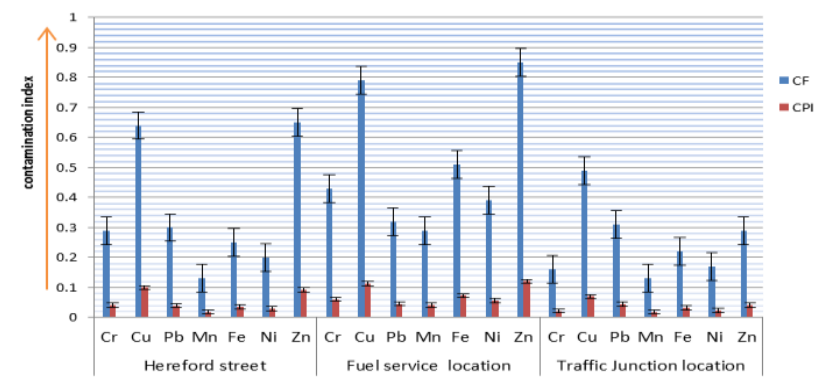

Fig. 3. Contamination factors (CF) and combined pollution index (CPI) of the heavy metals at the sampling sites.

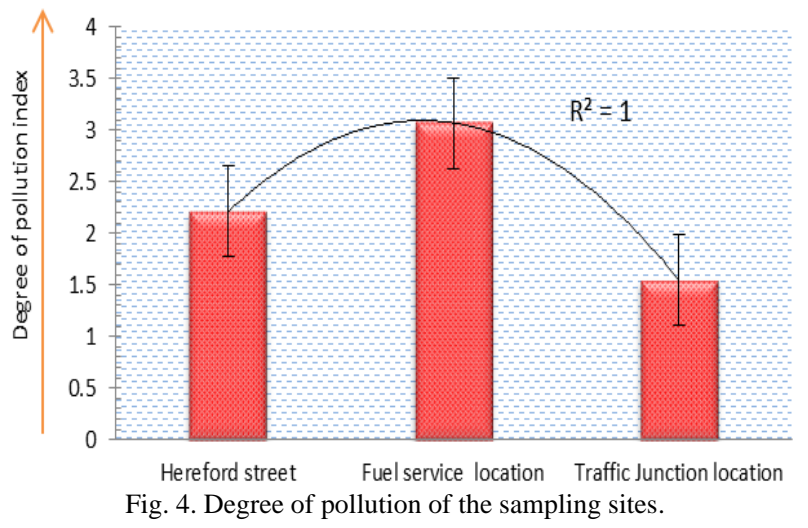

\section{Inter-elemental Correlation Analysis of the Heavy} Metals

The results of the correlation analysis between the mean levels of the heavy metals recorded across the sampling sites (Table $\mathrm{V}$ below ) mostly revealed strong ( $r>0.5$ to 0.9 ) to extremely strong $(r>0.9)$ positive correlations. Only $\mathrm{Pb}$ and $\mathrm{Zn}$ showed weak positive correlation $(r=0.3524)$. Generally, these correlation coefficients suggest common source of anthropogenic input of the heavy metals across the sampling sites. This is not surprising because the three sampling sites are different parts of the same geographical location and hence, could be affected by the same effects of trans-boundary pollution associated with dusts deposition. It has been reported that trans-boundary air pollution is a major source of environmental exposure to heavy metals and because of their persistence and potential for global 
atmospheric transfer; pollutants emitted into the atmosphere

areas [5]. from a particular source could affect even the most remote

TABLE IV: STANDARD CRITERIA FOR THE ASSESSMENT OF SAMPLing Site POLLUTION STATUS

\begin{tabular}{cccccc}
\hline \multicolumn{2}{c}{ Enrichment Factor } & \multicolumn{2}{c}{ Contamination Factor } & \multicolumn{2}{c}{ Degree of contamination } \\
\hline \multicolumn{2}{c}{ Classification } & Degree of enrichment & Classification & Contamination level & \multicolumn{2}{c}{ Classification } & Contamination level \\
\hline $\mathrm{EF}<2$ & Deficient to minimal & $\mathrm{CF}<1$ & Low & $C_{d}<5$ & low \\
$2 \leq \mathrm{EF}<5$ & Moderate & $1 \leq \mathrm{CF}<3$ & Moderate & $5 \leq C_{d}<10$ & moderate \\
$5 \leq \mathrm{EF}<20$ & Significant & $3 \leq \mathrm{CF}<6$ & Considerate & $10 \leq C_{d}<20$ & considerable \\
$20 \leq \mathrm{EF}<40$ & Very high & $\mathrm{CF} \geq 6$ & High & $C_{d} \geq 20$ & very high \\
$\mathrm{EF} \geq 40$ & Extremely high & & & &
\end{tabular}

TABLE V: CORRELATION COEFFICIENT BETWEEN THE HEAVy METALS ACROSS THE SAMPLING SiteS

\begin{tabular}{cccccccc}
\hline & $\mathrm{Cr}$ & $\mathrm{Cu}$ & $\mathrm{Fe}$ & $\mathrm{Pb}$ & $\mathrm{Mn}$ & $\mathrm{Ni}$ & $\mathrm{Zn}$ \\
\hline $\mathrm{Cr}$ & 1.0000 & & & & & & \\
$\mathrm{Cu}$ & 0.9998 & 1.0000 & & & & & \\
$\mathrm{Fe}$ & 0.9102 & 0.9011 & 1.0000 & & & & \\
$\mathrm{~Pb}$ & 0.5184 & 0.5000 & 0.8260 & 1.0000 & & & \\
$\mathrm{Mn}$ & 0.8765 & 0.8660 & 0.9972 & 0.8660 & 1.0000 & & \\
$\mathrm{Ni}$ & 0.9259 & 0.9177 & 0.9992 & 0.8030 & 0.9934 & 1.0000 & \\
$\mathrm{Zn}$ & 0.9830 & 0.9867 & 0.8185 & 0.3524 & 0.7731 & 0.8408 & 1.0000 \\
\hline
\end{tabular}

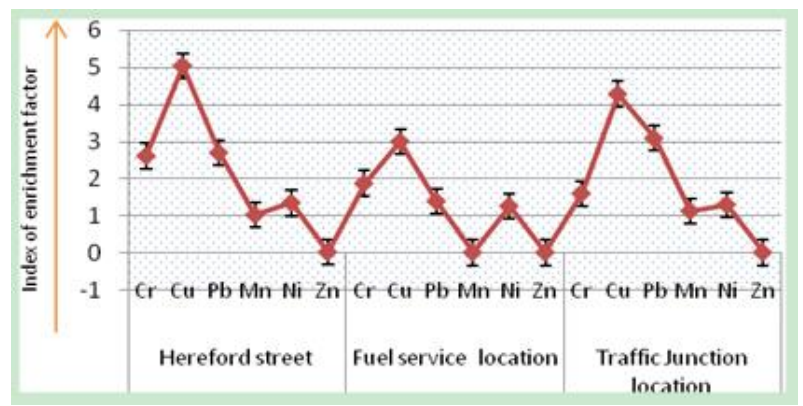

Fig. 5. Enrichment factors of the heavy metals at the sampling sites.

\section{CONCLUSION}

The results of this study revealed varying concentrations of chromium, lead, nickel, copper, iron manganese and zinc in the roadside dusts samples collected at Hereford street, fuel service station and traffic junction locations in the Monte Christo suburb of Windhoek, Namibia. Although, the present concentrations of the heavy metals were generally lower than the health regulatory maximum permissible limits in soils, their enrichment factors revealed deficient to minimal and significant indices. These suggest potentials for accumulation in the environment and people traversing the area as well as living within its vicinity may be at risk of exposure to the contaminant-bearing dusts via inhalation, dermal contact, ingestion and absorption. It is thus, recommended further research in this area should establish the impact of the different sources of metals emission on heavy metals' accumulations in the area. Such results could provide useful information guide for environmental management plan of Monte Christo in Windhoek which is currently undergoing fast developmental transformation.

\section{ACKNOWLEDGMENTS}

The authors wish to acknowledge the financial support from the Institutional Research and Publication Committee (IRPC) of the Namibia University of Science and Technology to undertake this study.

\section{REFERENCES}

[1] P. B. Tchounwou, C. G. Yedjou, A. K. Patlolla, and D. J. Sutton, "Heavy metal toxicity and the environment," EXS., vol. 101, pp. 133-164, 2012.

[2] J. Abah, P. Mashebe, S. A. Onjefu, and S. P. Malu, "Assessment of the In-situ concentrations of some heavy metals in surface soil dusts at the KatimaMulilo urban waste dumpsite, Namibia," Int. J. Adv. Sci Tech. Res., vol. 5, no. 4, pp. 88-100, 2015.

[3] C. R. Kimple and J. F. Morel, "Urban soil management: A growing concern," Soil Sci., vol. 165, pp. 31-40, 2000.

[4] D. S. Manta, M. Angelone, A. Bellanca, R. Neri, and M. Sprovieri, "Heavy metal in urban soils: A case study from the city of Palermo (Sicily), Italy," Sci. Total Environ., vol. 300, pp. 229-243, 2002.

[5] S. T. Ubwa, J. Abah, C. A. Ada, and E. Alechenu, "Levels of some heavy metals contamination of street dust in the industrial and high traffic density areas of Jos Metropolis," J. Biodiver. Environ. Sci., vol. 3, no. 7, pp. 13-21, 2013.

[6] Q. M. Jaradat and A. K. Momani, "Contamination of road side soil, plants, and air with heavy metals in Jordan: A comparative study," Turk J. Chem., vol. 23, pp. 209-220, 1999.

[7] E. A Ogbeibu, M. O. Omoigberale, I. M. Ezenwa, J. O. Eziza, and O. J. Igwe, "Using pollution load index and geoaccumulation index for the assessment of heavy metal pollution and sediment quality of the Benin River, Nigeria," Natural Environ., vol. 2, no. 1, pp. 1-9, 2014.

[8] J. Abah, P. Mashebe, and S. A. Onjefu, "Survey of the levels of some heavy metals in roadside dusts along KatimaMulilo Urban Road Construction, Namibia," Amer. J. Environ. Prot., vol. 3, no. 1, pp. 19-27, 2014.

[9] D. Meza-Figueroa, M. O-Villanueva, and M. L. Parra, "Heavy metal distribution in dust from elementary schools in Hermosillo, Sonora, Mexico," Atmosph. Environ., vol. 41, pp. 276-288, 2007.

[10] O. A. Al-Khashman, "Heavy metal distribution in dust, street dust and soils from the work place in Karak Industrial Estate, Jordan," Atmosph. Environ., vol. 38, pp. 6803-6812, 2004.

[11] H. Takada, T. Honda, M. Harada, and N. Ogura, "Distribution and sources of polycyclic aromatic hydrocarbons (PAHs) in street dust from the Tokyo Metropolitan area," Sci. Total Environ., vol. 107, pp. 45-69, 1991.

[12] N. M. Abdel-Latif and I. A. Saleh, "Heavy metals contamination in roadside dust along major roads and correlation with urbanization activities in Cairo, Egypt," J. Am. Sci.., vol. 8, no. 6, pp. 379-389, 2012. 
[13] X. Lu et al., "Contamination assessment of copper, lead, zinc, manganese and nickel in street dust of Baoji, NW China," J. Hazard. Mater., vol. 161, pp. 1058-1062, 2009.

[14] O. Morton-Bermea, E. Hernández-Álvarez, G. González-Hernández, F. Romero, R. Lozano, and L. E. Beramendi-Orosco, "Assessment of heavy metal pollution in urban topsoils from the metropolitan area of Mexico city," J. Geoch. Explor., vol. 101, pp. 218-224, 2009.

[15] B. Wei, F. Jiang, X. Li, S. Mu, N. Sezgin, H. K. Ozcan, G. Demir, S. Nemlioglu, and C. Bayat, "Determination of heavy metal concentrations in street dusts in Istanbul E-5 highway," Environ. Intern, vol. 29, pp. 979-985, 2003.

[16] S. Sindern, R. F. S. Lima, J. Schwarzbauer, and R. A. Petta, "Anthropogenic heavy metal signatures for the fast growing urban area of Natal (NE-Brazil)," Environ. Geolo., vol. 52, pp. 731-737, 2007.

[17] L. Ferreira-Baptista and E. Miguel, "Geochemistry and risk assessment of street dust in Luanda, Angola: A tropical urban environment," Atmos. Environ., vol. 39, no. 25, pp. 4501-4512, 2005.

[18] Y. Han, J. Cao, E. S. Posmentier, K. Fung, H. Tian, and Z. An, "Particulate-associated potentially harmful elements in urban road dusts in Xi'an, China," Appl. Geochem., vol. 23, pp. 835-845, 2008.

[19] G. Zhuang, R. Huang, M. Wang, Q. Zhou, J. Guo, H. Yuan, and Z. Rao, "Great progress in study on aerosol and its impact in the global environment," Prog. Natural Sci., vol. 12, no. 6, pp. 407-413, 2002.

[20] L. Han, G. Zhuang, S. Cheng, Y. Wang, and J. Li, "Characteristics of re-suspended road dust and its impact on the atmospheric environment in Beijing," Atmos. Environ., vol. 41, pp. 7485-7499, 2007.

[21] A. Aksoy and D. Demirezen, "Fraxinus excelsior as a biomonitor of heavy metal pollution," Pol. J. Environ. Stud.,, vol. 15, pp. 27-33, 2006.

[22] H. Maring, D. L. Savoie, M. A. Izaguirre, L. Custals, and J. S. Reid, "Mineral dust aerosol size distribution change during atmospheric transport," J Geophys. Res., vol. 108, no. 19, pp. 85-92, 2003.

[23] P. L. Kinney and M. Lippmann, "Respiratory effects of seasonal exposures to ozone and particles," Arch. Environ. Health, vol. 55, pp. 210-216, 2000.

[24] J. N. Edokpayi, J. O. Odiyo, and S. O. Olasoji, “Assessment of heavy metal contamination of Dzindiriver, in Limpopo Province, South Africa," Inter. J. Nat. Sci. Res., vol. 2, no. 10, pp. 185-194, 2014.

[25] C. Ewan, M. A. Anagnostopoulou, and N. I. Ward, "Monitoring of heavy metal levels in roadside dusts of Thessaloniki, Greece in relation to motor vehicle traffic density and flow," Environ. Monit. Assess., vol. 157, no. 1-4, pp. 483-98, 2009.

[26] N. I. Ward, A. Dudding, and M. Lyndon, "Platinum emissions and levels in motorway dust samples: influence of traffic characteristics," Sci. Total Environ., pp. 334- 335, 457-463, 2004.

[27] EPA, Method 3050B, acid digestion of sediments, sludge, and soils. 1996.

[28] M. A. Nasser and A. S. Inas, "Heavy metals contamination in roadside dust along major roads and correlation with urbanization activities in Cairo, Egypt,” J. Ame. Sci., vol. 8, no. 6, pp. 379-389, 2012.

[29] J. Emsley, Nature's Building Blocks: An A-Z Guide to the Elements," Oxford University Press, 2001.

[30] J. M. Deely and J. E. Fergusson, "Heavy metal and organic matter concentration and distributions in dated sediments of a small estuary adjacent to a small urban area," Sci. Total Environ., vol. 153, no. 1-2, pp. $97-111,1994$.

[31] SourceWatch. (2016). Van Eck Power Station. [Online]. Available: www.sourcewatch.org/index.php/Van_Eck_Power_Station

[32] J. A. Markus and A. B. McBratney, "An urban soil study: Heavy metals in Glebe, Australia," Aust. J. Soil Res., vol. 34, pp. 453-465, 1996.

[33] W. Wilcke, M. Silke, K. Nualsri, and Z. Wolfgang, "Urban soil contamination in Bangkok: Heavy metal and aluminium portioning in topsoils," Geoderma, vol. 86, pp. 211-228, 1998.
[34] M. Winther and E. Slento, "Heavy metal emissions for Danish road transport; NERI technical report No. 780," Aarhus Universitet, Roskilde, Denmark, 2010.

[35] IEA Clean Coal Centre. (2012). Trace element emissions from coal, No 12/13. [Online]. Available: http://www.iea-coal.org.uk/documents/83083/8631/Trace-element-em issions-from-coal,-CCC/203

[36] A. S. Ayangbenro and O. O. Babalola, "A New strategy for heavy metal polluted environments: a review of microbial biosorbents," Inter J. Environ. Resour. Pub.Health., vol. 14, no. 94, pp. 1-16, 2017.

[37] T. M. Chiroma, R. O. Ebewele, and F. K. Hymore, "Comparative assessment of heavy metal levels in soil, vegetables and urban grey waste water used for irrigation in Yola and Kano," Inter. Ref. J. Eng. Sci., vol. 3, no. 2, pp. 1-9, 2014.

[38] J. Abah, P. Mashebe, and S. A. Onjefu, "Heavy metals content of the grassland soil around KatimaMulilo Municipality solid waste dumpsite, Namibia,” Ame. J. Environ. Sci., vol. 13, no. 2, pp. 128-137, 2017.

[39] M. C. Jung, "Heavy metal contamination of soils and waters in and around the Imcheon Au-Ag Mine, Korea," Appl. Geochem, vol. 16, no. 11, pp. 1369-1375, 2001

[40] S. H. Rahman, D. Khanam, T. M. Adyel, M. S. Islam, and M. A. Ahsan, "Assessment of heavy metal contamination of agricultural soil around Dhaka Export Processing Zone (DEPZ), Bangladesh: Implication of seasonal variation and indices," Applied Sc., vol. 2, pp. 584-601, 2012.

[41] R. Singh, N. Gautam, A. Mishra, and R. Gupta, "Heavy metals and living systems: An overview," Ind. J. Pharm., vol. 43, no. 3, pp. 246253,2011

[42] V. Rajaganapathy, F. Xavier, D. Sreekumar, and P. K. Manda, "Heavy metal contamination in soil, water and fodder and their presence in livestock and products: a review," J. Environ. Sci. Tecne, vol. 4, pp. 234-249, 2011

[43] Y. Hu, X. Liu, J. Bai, K. Shih, E. Y. Zeng, and H. Cheng, “Assessing heavy metal pollution in the surface soils of a region that had undergone three decades of intense industrialization and urbanization,' Environ. Sci. Pollut. Res., vol. 20, pp. 6150-6159, 2013.

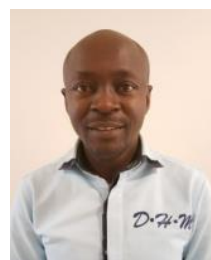

S. A. Onjefu was born in Nigeria. He obtained his bachelor of science (B.Sc hons) in 2000 from Benue State University, Makurdi, the master of science (M.Sc) environmental physics from the Federal University of Agriculture Makurdi, in 2006 and the doctor of philosophy ( $\mathrm{PhD})$, physics from the North West University South Africa in 2016. He worked as lecturer at Benue State College of Education Oju and Western Delta University Oghara, Delta State, Nigeria and presently a lecturer at the Namibia University of Science and Technology. S.A Onjefu has published widely in international peer-reviewed journals and has his research interest in aerosol science and environmental physics.

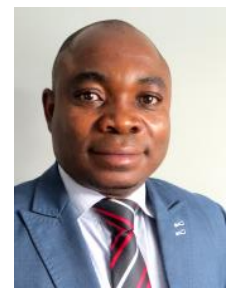

J. Abah was born in Nigeria in 1978. He obtained his bachelor of science (B.Sc Hons) ( $2^{\text {nd }}$ Class Upper Division) in 2002 from Benue State University, Makurdi, the master of science (M.Sc) analytical chemistry and the doctor of philosophy $(\mathrm{PhD})$, analytical chemistry, both from the University of Maiduguri Nigeria in 2006 and 2010 respectively. He worked as Lecturer II at Yobe State Polytechnic, Geidam and Fedederal Plytechnic, Nasarawa, Reserch officer I and Senior Research Scientist at National Cereals Research Institute, Badeggi, Lecturer at Benue State University, Makurdi and presently a Senior Lecturer at the University of Namibia. J. Abah is a seasoned researcher and has published widely in international peer-reviewed journals. His research interest is in environmental pollution and remediation. 